\title{
15 LAT PAŃSTW BAŁTYCKICH W UNII EUROPEJSKIEJ W ŚWIETLE BADAŃ OPINII PUBLICZNEJ - PRÓBA BILANSU
}

\author{
Liliana Węgrzyn-Odzioba \\ Uniwersytet Marii Curie-Skłodowskiej w Lublinie \\ Katedra Stosunków Międzynarodowych \\ ORCID ID: https://orcid.org/0000-0002-3897-8843 \\ e-mail: liliana.wegrzyn-odzioba@poczta.umcs.lublin.pl
}

\begin{abstract}
Streszczenie: W państwach bałtyckich zarówno na etapie akcesji jak i obecnie widać wysokie poparcie dla Unii Europejskiej. Celem artykułu jest analiza procesu wstąpienia trzech państw bałtyckich do Unii Europejskiej oraz bilans piętnastu lat w tej organizacji. Przedmiotem badań będzie również społeczny odbiór integracji europejskiej w tych państwach.
\end{abstract}

Słowa kluczowe: państwa bałtyckie, Unia Europejska, opinia publiczna

\section{WSTĘP}

Integracja Litwy, Łotwy i Estonii ze strukturami europejskimi 1 maja 2004 roku spowodowała, że Bałtyk został morzem wewnętrznym Unii Europejskiej, a integracja europejska wkroczyła na nowe tory. Państwa bałtyckie przez wiele lat postrzegane w polityce międzynarodowej albo jako byłe republiki ZSRR albo satelici państw skandynawskich ${ }^{1}$ wyznaczyły nową perspektywę dla pogłębiania współpracy paneuropejskiej. Trzem państwom bałtyckim przez długi czas udawało się dzięki pogłębionej współpracy zaistnieć w świadomości Europejczyków. Swoim dążeniom do niepodległości państwa bałtyckie dały wyraz już w 1986 roku kiedy to w ramach tak zwanej „Grupy Helsinki”(inaczej Helsinki 86) unieważniono Pakt Ribbentrop-Mołotow oraz uznano włączenie do ZSSR za okupację². Szerokim echem

1 Toomas Hendrik Ilves, wybrany na drugą kadencje prezydent Estonii ujął to następująco: „Estonia to postsocjalistyczny kraj skandynawski"

2 Ruch oporu wobec rusyfikacji istniał w tych państwach od zakończenia II wojny światowej, na sile przybrał w od początku lat osiemdziesiątych, w Estonii szczególnie widoczny w okresie tak zwanej 
odbił się również zorganizowany w pięćdziesiątą rocznicę podpisania tego paktu 23 sierpnia 1989 roku wiec w ramach którego utworzono żywy liczący 600 kilometrów łańcuch łączący Wilno i Tallin. W 1990 roku powstała Rada Bałtycka jako przymierze polityczne Estonii, Litwy i Łotwy mające na celu koordynację polityki zagranicznej zwłaszcza wobec Wspólnoty Niepodległych Państw. Bardzo wcześnie, bo już 1993 roku państwa bałtyckie wyznaczyły również swój kurs na Zachód ${ }^{3}$. Lenart Merci - pierwszy prezydent Estonii jeszcze przed objęciem tego stanowiska jako minister spraw zagranicznych w 1990 roku wskazał na doświadczenia z przeszłości które powodują, że „powrót” do Europy jest jedyną możliwą alternatywą ${ }^{4}$ W związku ze ścisłymi powiązaniami ekonomicznymi i sukcesem gospodarczym wielu publicystów nazywało państwa bałtyckie Beneluksem wschodu lub „europejskimi tygrysami”. Niewątpliwie państwa te w momencie uzyskania niepodległości miały zbliżoną pozycję i potencjał, tym niemniej Estonia niemal od początku zdystansowała się od swoich partnerów przyjmując radykalne rozwiązania jeśli chodzi o politykę i gospodarkę jednocześnie zaś wykorzystała swoje sąsiedztwo z Finlandią i płynące szerokim strumieniem inwestycje zagraniczne. Łotwa i Litwa wybrały drogę stopniowej transformacji systemów politycznych i gospodarczych. Widać było jednak wyraźnie próby wprowadzania rozwiązań i mechanizmów charakterystycznych dla państw Europy Zachodniej ${ }^{5}$. Droga państw bałtyckich do Unii Europejskiej została poprzedzona ich akcesją do innych organizacji - w 1991 roku zostały one przyjęte do Organizacji Bezpieczeństwa i Współpracy w Europie, w 1993 roku Estonia i Łotwa, zaś w 1995 Litwa zostały włączone do Rady Europy, w tym samym roku zawarto porozumienie

\footnotetext{
„śpiewającej rewolucji” w 1988 roku, w latach 1988 i 1989 na Łotwie powstały opozycyjne Łotewski Front Ludowy, Łotewski Ruch Niepodległości Narodowej, zob. więcej: P. Van Elsuwege From Soviet Republics to EU Member States: A Legal and Political Assessment., Koninklijke Brill NV 2008, s. 43-49, tekst rezolucji potępiającej zbrodnie stalinowskie: http://www.letton.ch/lvx_tall4.htm, 6.12.21.

3 Chociaż obecnie zwraca się uwagę na to Estonia związała się ze Skandynawią, Litwa ,ciąży” w kierunku Europy Środkowowschodniej, natomiast Łotwa zmierza ku Rosji. W przypadku Litwy przyjęta zachodnia orientacja nie była jedyną brana pod uwagę, w toku dyskusji po odzyskaniu niepodległości brano pod uwagę cztery warianty: a)samodzielność i neutralność, b)związek dwóch lub więcej małych państw, c)członkowstwo w wielostronnym sojuszu, d) dwustronny sojusz z mocarstwem regionalnym, Miniotaitė G., Jakniūnaitė D., 2001, Lietuvos saugumo politika ir identitetas šiuolaikiniu saugumo studiju kontekste, Politologia 3, s. 21-34, http://edvardas.home.mruni.eu/ wp-content/uploads/2011/09/LT-saugumas-pagal-siuolaikines-teorijas.pdf, 2.12.21.

4 M. Lahti, 2005, Estonia and Latavia: A New Europe challenges the „old”, w: The Balic States, Amsterdam, New York, s.96-97.

5 Państwa bałtyckie funkcjonują w postsowieckim systemie elektroenergetycznym (IPS/ UPS), łączącym je z Rosją i Białorusią. Ze względu na uwarunkowania geopolityczne i zauważalne zagrożenie ze strony Rosji podejmowane są inicjatywy mające na zadanie uniezależnienie się od rosyjskiego operatora. W ostatnich latach Litwa, Łotwa i Estonia rozbudowały połączenia elektroenergetyczne z Finlandią, ze Szwecją i z Polską (EstLink1 i 2, NordBalt, LitPolLink1). Cały proces w założeniu ma się zakończyć w 2025 roku, K. Raś, (2017), Elektroenergetyka - kolejny cel państw bałtyckich w uniezależnianiu się od Rosji, Biuletyn PISM, Nr 56 (1498).
} 
ramowe umowy o stosunkach z Unią Europejską oznaczające przyznanie statusu członka stowarzyszonego aplikującego o członkostwo.

Minister spraw zagranicznych Łotwy Artis Fabriks na XVI Konferencji Parlamentów Państw Morza Bałtyckiego w grudniu 2007 roku stwierdził: „nie wyglądamy tak samo, nie mówimy jednym językiem, nie żyjemy w jednym kraju, nie mamy wspólnej drużyny hokejowej ani w żadnej innej dziedzinie sportu. Ale łączy nas Bałtyk, wspólna historia, wartości i energia, dynamizm, zdolności i kreatywność. Ponadto, co najważniejsze, podzielmy wspólne marzenia o przyszłości naszego regionu, aby był postępowy, stabilny, konkurencyjny i zawsze rozwijający się" . W sierpniu 2012 roku agencje prasowe obiegły z kolei słowa prezydenta Łotwy Andrisa Berzinša który stwierdził, iż brak współpracy między państwami bałtyckimi spowoduje ich zniknięcie z mapy Europy ponieważ są to zbyt małe państwa jak na samodzielny byt międzynarodowy?

Wprowadzenie przez Estonię waluty euro w sytuacji pogłębiającego się kryzysu gospodarczego przez zagraniczne media zostało odnotowane jako niezwykle pozytywne wydarzenie. Ten niewątpliwy sukces wizerunkowy jednocześnie jest często traktowany jako emancypację Estonii z grupy państw bałtyckich. Wskazuje się przy tym, że Estonia wyraźnie ciąży ku państwom skandynawskim i wyraźnie odbiega od Litwy i Łotwy swoim potencjałem. Obecnie pozycja geopolityczna państw bałtyckich oraz ich potencjał i zaplecze gospodarcze powodują, że stają się one centralnymi zwornikami projektów infrastrukturalnych związanych z taki dziedzinami jak energia, transport, bezpieczeństwo ekologiczne oraz współpraca naukowo- techniczna. Procesy te pozwalają na sformułowanie stwierdzenia, że państwa bałtyckie stały się tak ważnym członkiem Unii Europejskiej, iż wzmocnieniem struktur powiązanych co prawda z Unia Europejską ale skierowanych ku państwom skandynawskim takim jak Rada Państw Morza Bałtyckiego czy powrót do koncepcji Bałtoskandynawii(czy grupy NB8) ${ }^{8}$ widoczne w polityce tych państw budzą uzasadniony niepokój partnerów unijnych.

We wszystkich państwach bałtyckich zarówno na etapie akcesji jak i obecnie widać wysokie poparcie dla Unii Europejskiej. Dlatego celem artykułu jest analiza procesu wstąpienia trzech państw bałtyckich do Unii Europejskiej oraz bilans piętnastu lat $\mathrm{w}$ tej organizacji na tle badań opinii publicznej i analizy społecznego poparcia dla podjętej trzydzieści lat temu inicjatywy. Zgromadzony materiał badawczy stanowią dostępna literatura, dane statystyczne i sondażowe badania opinii publicznej.

6 Państwa bałtyckie w zintegrowanej Europie, red. J.W. Gołębiowski, Warszawa 2011, wstęp, s. 19.

7 Temat utworzenia wspólnego państwa był dyskutowany od lat 30-tych XX wieku, http:// wiadomosci.onet.pl/swiat/prezydent-lotwy-panstwa-baltyckie-moga-zniknac,1,5207113, wiadomosc. html, 12.09.21.

8 http://www.xxiamzius.lt/archyvas/priedai/horizontai/20030820/2-1.html, 25.09.20. 


\section{INTEGRACJA ZE STRUKTURAMI UNII EUROPEJSKIEJ}

Od 1 maja 2004 roku Unia Europejska liczyła 25 członków. Droga do pełnego członkowstwa w strukturach unijnych dla państw bałtyckich była skomplikowana. Po nawiązaniu stosunków z państwami Europy po odzyskaniu niepodległości i podpisaniem w maju 1992 roku umowy o handlu i współpracy z Unia Europejską. Od 1994 roku proces zbliżania z UE nabrał prędkości.

Zawarcie umów o wolnym handlu między Unią a Estonią, Łotwą i Litwą 18 lipca 1994 roku było ważnym momentem i spowodowało przyśpieszenie współpracy i rozpoczęcie w grudniu tego roku negocjacji układów o stowarzyszeniu. Od początku najbardziej elastyczne stanowisko zajęła Estonia uznając, że godzi się na wszystkie warunki Unii. Stąd też negocjacje z państwami bałtyckimi zakończyły się już w marcu 1995 roku a umowy o stowarzyszeniu zostały podpisane 12 czerwca 1995 roku. W grudniu 1995 roku w Madrycie Rada Unii Europejskiej zleciła Komisji Europejskiej przygotowanie opinii o wniosku o członkostwo dla krajów, które wyraziły chęć znalezienia się w Unii Europejskiej. Jednocześnie od tego roku ku niezadowoleniu Litwy i Łotwy, Estonia zaczęła coraz wyraźniej akcentować swoje niezależne stanowisko na co niewątpliwie wpływało zarówno wsparcie ze strony państw nordyckich jak i silniejsza potrzeba integracji ze strukturami NATO9.

31 marca 1998 roku oficjalnie rozpoczęto proces negocjacji dla dziesięciu kandydatów. Przegląd dostosowania ich porządku prawnego do prawa unijnego, tak zwanego screening, objął dziesięć państw Europy Środkowej i Wschodniej, z tym, że w przypadku Bułgarii, Rumunii, Łotwy, Litwy i Słowacji screening polegać miał na wyjaśnieniu przez Komisję istoty zobowiązań składających się na unijny porządek prawny, natomiast bardziej zaawansowana piątka, czyli Polska, Czechy, Węgry, Estonia i Słowenia przystąpiły do właściwych negocjacji akcesyjnych w siedmiu dziedzinach unijnego dorobku prawnego.

Dziesięć państw europejskich w tym Litwa, Łotwa i Estonia podpisało 16 kwietnia 2003 roku traktat akcesyjny do Unii Europejskiej. Traktat sporządzony został w 21 językach oficjalnych państw, czyli 15 państw członkowskich Unii i 10 przystępujących do Unii. Struktura traktatu obejmowała trzy zasadnicze dokumenty:

9 Należy pamiętać, że Estonia obok problemów z mniejszością rosyjskojęzyczną miała również nierozwiązany konflikt graniczny z Rosją, traktat graniczny przygotowany w 1996 roku został podpisany dopiero w maju 2005 roku, w dokumencie ratyfikowanym przez parlament Estonii znalazło się szereg zapisów m.in. uznające włączenie Estonii do ZSRR za aneksję(spór terytorialny dotyczył 5\% ziem włączonych w 1940 roku do Rosyjskiej Republiki Radzieckiej), ostatecznie prezydent Władimir Putin wycofał swój podpis; na poprawę sytuacji nie wpływały korzystnie ani proeuropejskie dążenia Estonii ani próby blokowania przez Rosję wstąpienia Estonii do NATO czy próby marginalizowania znaczenia Estonii w polityce NATO. 
- akt o przystąpieniu - właściwy traktat akcesyjny - stanowi o członkostwie państwa w $\mathrm{UE}^{10}$

- akt o warunkach przystąpienia - reguluje warunki uzyskania członkostwa przez państwo ${ }^{11}$,

- akt końcowy - oświadczenia państw członkowskich i państwa przystępującego $^{12}$.

Tabela 1. Przegląd drogi do akcesji państw bałtyckich

\begin{tabular}{|c|c|}
\hline data & kroki \\
\hline $\begin{array}{c}13.10 .1995 \text { (Lotwa) } \\
24.11 .1995 \text { (Estonia) } \\
8.12 .1995 \text { (Litwa) }\end{array}$ & $\begin{array}{c}\text { Państwa bałtyckie zgłosiły aplikację na członków UE do Komisji Euro- } \\
\text { pejskiej; }\end{array}$ \\
\hline $15-16.12 .1995$ & $\begin{array}{c}\text { Na szczycie madryckim poproszono Komisję o opinię na temat człon- } \\
\text { kowstwa państw Europy Środkowo- Wschodniej; }\end{array}$ \\
\hline 15.06 .1997 & $\begin{array}{c}\text { Komisja po przedstawieniu Opinii zarekomendowała rozpoczęcie nego- } \\
\text { cjacji z Cyprem, Czechami, Polska, Estonia, Węgrami i Słowenia(1+5) } \\
\text { ale nie z Bułgarią, Lotwą, Litwą, Rumunią i Słowacją; }\end{array}$ \\
\hline 12.12 .1997 & $\begin{array}{c}\text { Komisja Europejska wydała rekomendacje do rozpoczęcia negocjacji } \\
\text { z państwami grupy 1+5 i coroczne spotkania w celu przeglądu procesu } \\
\text { negocjacyjnego jako ,częśc wdrażania Art. O(art.49 EU) Traktatu o Unii } \\
\text { Europejskiej; }\end{array}$ \\
\hline 31.03 .1998 & $\begin{array}{c}\text { Konferencja międzyrządowa otwarła negocjacje z Cyprem, Węgrami, } \\
\text { Polska, Estonią, Czechami i Słowenią; }\end{array}$ \\
\hline 13.10 .1999 & $\begin{array}{c}\text { Komisja zarekomendowała rozpoczęcie negocjacji z Bułgarią, Litwą, } \\
\text { Łotwą, Maltą, Rumunią i Słowacją; }\end{array}$ \\
\hline $10-11.12 .1999$ & Rada w Helsinkach zarekomendowała rozpoczęcie negocjacji ze wszyst- \\
& kimi państwami kandydującymi z wyjątkiem Turcji; \\
\hline $12-13.12 .2002$ & W Kopenhadze przyjęto wnioski negocjacyjne od 10 państw; \\
\hline 19.022003 & Komisja przedstawiła ostateczną opinię o Traktacie; \\
\hline 9.04 .2003 & Parlament Europejski większością głosów przyjmuje \\
& Traktaty Akcesyjne; \\
\hline
\end{tabular}

${ }^{10}$ Traktat między Królestwem Belgii, Królestwem Danii, Republiką Federalną Niemiec, Republiką Grecką, Królestwem Hiszpanii, Republiką Francuską, Irlandią, Republiką Włoską, Wielkim Księstwem Luksemburga, Królestwem Niderlandów, Republiką Austrii, Republiką Portugalską, Republiką Finlandii, Królestwem Szwecji, Zjednoczonym Królestwem Wielkiej Brytanii i Irlandii Północnej (Państwami Członkowskimi Unii Europejskiej) a Republiką Czeską, Republiką Estońską, Republiką Cypryjską, Republiką Łotewską, Republiką Litewską, Republiką Węgierską, Republiką Malty, Rzecząpospolitą Polską, Republiką Słowenii, Republiką Słowacką dotyczący przystąpienia Republiki Czeskiej, Republiki Estońskiej, Republiki Cypryjskiej, Republiki Łotewskiej, Republiki Litewskiej, Republiki Węgierskiej, Republiki Malty, Rzeczypospolitej Polskiej, Republiki Słowenii, Republiki Słowackiej do Unii Europejskiej, http://eur-lex.europa.eu/pl/treaties/dat/12003T/htm/12003T.html, 12.12.20.

${ }^{11}$ Akt dotyczący warunków przystąpienia do Unii Europejskiej Republiki Czeskiej, Republiki Estońskiej, Republiki Cypryjskiej, Republiki Łotewskiej, Republiki Litewskiej, Republiki Węgierskiej, Republiki Malty, Rzeczypospolitej Polskiej, Republiki Słowenii i Republiki Słowackiej oraz dostosowań w Traktatach stanowiących podstawę Unii Europejskiej, http://eur-lex.europa.eu/pl/ treaties/dat/12003T/htm/12003T.html, 12.12.20.

12 Akt końcowy, http://eur-lex.europa.eu/pl/treaties/dat/12003T/htm/12003T.html, 12.12.20. 


\begin{tabular}{|c|c|}
\hline data & kroki \\
\hline 14.04 .2003 & Rada przyjęła Traktat Akcesyjny; \\
\hline 16.04 .2003 & Podpisano Traktaty Akcesyjne; \\
\hline 10/11. 05.2003 (Litwa) & Państwa bałtyckie ratyfikowały Traktat Akcesyjny po uzyskaniu akcepta- \\
14.08.2003 (Estonia) & cji społecznej w referendach; \\
20.08 .2003 (Lotwa) & \\
\hline 1.05 .2004 & Wstąpienie państw bałtyckich do Unii Europejskiej \\
\hline
\end{tabular}

Źródło: P. Van Elsuwege From Soviet Republics to EU Member States: A Legal and Political Assessment., Koninklijke Brill NV 2008, s.201-202.

\section{REFERENDA AKCESYJNE}

Najwcześniej referendum odbyło się na Litwie gdzie w dwudniowym głosowaniu dopuszczającym możliwość korzystania z Internetu Litwini odpowiadali na pytanie "Czy popierasz członkostwo Republiki Litewskiej w Unii Europejskiej". Frekwencja w referendum wyniosła ponad 64\% uprawnionych do głosowania, z czego $91 \%$ obywateli Litwy powiedziało "tak" dla integracji europejskiej, natomiast przeciwnego zdania było niespełna $9 \%$ głosujących ${ }^{13}$.

Estońskie referendum odbyło się 14 września 2003 roku. Wydarzenie to było szeroko komentowane przez zagraniczne media. Pomimo wcześniejszych obaw wyniki okazały się korzystne dla euroentuzjastów. W odpowiedzi na pytanie "Czy jesteś za przystąpieniem do Unii Europejskiej oraz za przyjęciem poprawek do konstytucji Republiki Estonii?", za opowiedziało się 66,92 \% obywateli natomiast przeciwników było 33,08 \%. Frekwencja w referendum wyniosła 63\%. Ostateczną decyzję w sprawie przystąpienia Estonii do UE podjął estoński parlament.

Kampania informacyjna prowadzona była przez Ministerstwo Spraw Zagranicznych i zasadniczo ograniczyła się do przygotowania strony internetowej oraz publikowania materiałów informacyjnych ${ }^{14}$.

Badania potwierdziły pozytywny odbiór Unii Europejskiej w społeczeństwie estońskim, zwłaszcza wśród osób pracujących, przed pięćdziesiątym rokiem życia i mieszkających w dużych ośrodkach. Podobnie jak w innych państwach pojawiły się tematy szczególnie trudne w kontekście integracji. I tak w Estonii 40\% respondentów zwróciło uwagę na dwa problemy z jakimi wiązali przystąpienie do Wspólnot: kwestia estońskiego rolnictwa i relacji z Rosją, choć według ekspertów i części elit obawy te były przesadzone, wskazywano bowiem, że bez wsparcia

13 http://www.cie.gov.pl/www/serce.nsf/0/DCC17BDA224BBEB9C1256E83003DD8FB?Open\&RestrictToCategory=\#2, 13.12.20.

${ }_{14}$ Wcześniej, bo już w roku 1997 przeprowadzono w Estonii na grupie 300 osób w Tallinie, Tartu i Ida- Viru badania opinii publicznej w ramach których zanalizowano główne obszary na które Unia według respondentów będzie miała wpływ. 
Unii nie udałoby się tak skutecznie zrestrukturyzować rolnictwa, a i stosunki z Rosją systematycznie po wstąpieniu do Unii normalizowały się ${ }^{15}$.

1 września 2003 roku w Tallinie komisarz ds. rozszerzenia Günter Verheugen namawiał Estończyków do głosowania za przystąpieniem Estonii do UE. Na spotkaniu z dziennikarzami stwierdził: „Historia i geografia wskazują, że Estonia potrzebuje stabilności i bezpieczeństwa, zarówno w sensie politycznym, jak i ekonomicznym, co zapewnia integracja z UE. Przypuszczam, że wynik referendum będzie pozytywny. Jest to najpoważniejsza decyzja od czasu odzyskania niepodległości, decyzja dla następnych pokoleń”'16.

Członkostwo Estonii w UE poparł estoński Kościół Ewangelicki. Natomiast wyraźnie przeciwko opowiedziała się Partia Centrum wskazując na zagrożenia związane z utratą suwerenności i gospodarczymi kosztami integracji.

Na Łotwie referendum odbyło się 20 września 2003 roku. Na pytanie: , Czy popierasz czlonkostwo Lotwy w Unii Europejskiej?" z 72,5 procent uprawnionych głosujących za opowiedziało się 67 procent natomiast przeciw było 32,3 procent ${ }^{17}$. Poparcie dla integracji wyraziły wszystkie Patrie polityczne, a także kościoły prawosławny i katolicki. Przedreferendalna kampania miała podobnie jak w innych państwach przybliżyć obywatelom Unię Europejską. Obok oficjalnej kampanii rządowej w działania promocyjne włączyło się osiem organizacji pozarządowych które uzyskały finansowe wsparcie z Przedstawicielstwa Komisji Europejskiej na Łotwie.

W celu poparcia kampanii informacyjnej na rzecz członkowstwa w Unii Europejskiej premierzy państw bałtyckich 22 sierpnia 2003 roku Juhan Parts, Algirdas Brazauskas i Einars Repse wydali wspólne oświadczenie, w którym wyrazili poparcie dla przystąpienia wszystkich trzech państw bałtyckich do UE. Jednocześnie zaapelowali do mieszkańców Estonii i Łotwy aby wzorem Litwinów wypowiedzieli się ze przystąpieniem do Unii ${ }^{18}$. Komisarz ds. poszerzenia Günter Verheugen po otrzymaniu informacji o pozytywnym wyniku referendum na Łotwie powiedział: "To wielki dzień dla wszystkich Europejczyków. Witamy kraj, który w sposób naturalny do nas przynależy. Ufamy, że Łotwa, tak jak inne przyszłe państwa członkowskie, wzbogaci i umocni Unię. Witaj w domu Łotwo!"19.

${ }_{15}$ T. Trocikowski, Stopień poparcia społeczeństwa Estonii dla integracji z Unia Europejska http://www.exporter.pl/forum/rynki_wschodnie/Estonia_unia.html, 30.12.20, por również: Obawy i nadzieje społeczeństwa Estonii związane z integracja z strukturami Unii Europejskiej w kontekście referendum akcesyjnego, „Annales Academiae Paedagogicae Cracoviensis. Studia Politologica III”, Wydawnictwo Naukowe Akademii Pedagogicznej, Kraków 2007, s. 151 -169.

16 Tamże.

${ }^{17}$ U. Kaiser, The Balic States As Members of the European Union- an Analysis of the public opinion to EU membership in the Baltic Region, GRIN Verlag 2005, s.11.

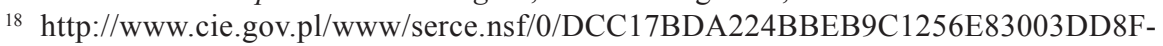
B?Open\&RestrictToCategory=\#2, 13.12.20.

19 Tamże. 


\section{INTEGRACJA GOSPODARCZA}

Największe różnice w przypadku państw bałtyckich występują przy analizie rozwoju ich gospodarek po $1990 \mathrm{roku}^{20}$. Estonia po ogłoszeniu niepodległości została wsparta inwestycjami ze strony państw skandynawskich i koncernów Nokia oraz Ericsson, tym samym postawiła na rozwój Internetu, nowych technologii i w konsekwencji jej gospodarka jest analizowana jako tak zwana gospodarka oparta na wiedzy $(\mathrm{GOW})^{21}$. Z kolei Łotwa skupiła się na rozwoju bankowości między innymi dzięki napływającymi do rosyjskojęzycznej Rygi milionerami z byłego ZSRR. Litwa natomiast postawiła na zbliżenie ze strukturami Unii w celu pozyskania jak największych kwot pomocowych skierowanych na rozwój gospodarki. Tym niemniej początek lat dziewięćdziesiątych wraz z załamaniem stosunków gospodarczych z Rosją i upadkiem handlu zagranicznego spowodował recesję. W najgorszym, 1992 roku spadek realnego PKB wyniósł - 14,2\% dla Estonii, $-34,9 \%$ dla Łotwy i $-21,3 \%$ dla Litwy ${ }^{22}$. Podjęto wtedy szereg radykalnych kroków m.in. dzięki wsparciu Międzynarodowego Funduszu Walutowego wprowadzono reformę walutową ${ }^{23}$, przyspieszono przekształcenia własnościowe oraz konsekwentnie utrzymywano dyscyplinę w zakresie finansów publicznych ${ }^{24}$. Lata 1996 - 2004, czyli tuż przed akcesją do UE to okres stabilizacji i wzrostu gospodarek państw bałtyckich ze szczególnym wskazaniem na fenomen Estonii. Inwestycje zagraniczne spowodowały olbrzymi boom gospodarczy, jednocześnie w każdym z państw ożywił się rynek nieruchomości. Dynamika wzrostu była bardzo wysoka stawiając państwa bałtyckie w czołówce wśród kandydatów do Unii Europejskiej, tym samym ich pozycja w Europie znacznie wzrosła (tab. nr 1).

Tabela 2. PKB PPS postsowieckich państw bałtyckich, na 1 mieszkańca w \% średniej UE-27(UE-27=100)

\begin{tabular}{|c|r|r|r|c|c|c|}
\hline Państwo & 1996 & 2000 & 2004 & $\begin{array}{c}\text { Zmiana w punktach } \\
\text { procentowych } \\
\text { w latach 1996-2004 }\end{array}$ & $\begin{array}{c}\text { Zmiana w punktach } \\
\text { procentowych } \\
\text { w latach 2000-2004 }\end{array}$ & $\begin{array}{c}\text { Zmiana w punktach } \\
\text { procentowych } \\
\text { w latach 1996-2004 }\end{array}$ \\
\hline UE 15 & 115,7 & 115,2 & 113,2 & $-0,5$ & $-2,0$ & $-2,5$ \\
\hline Estonia & 38,0 & 45,0 & 57,4 & 7,0 & 12,4 & 19,4 \\
\hline
\end{tabular}

${ }^{20}$ Więcej na temat transformacji ekonomiczne państw bałtyckich: W. Kosiedowski, Transformacja systemowa państw baltyckich, w: Państwa baltyckie w zintegrowanej Europie, red. J.W. Gołębiowski, Warszawa 2011, s. 23-43.

${ }_{21}$ M. Rutkiewicz-Wardyn, Estońska droga ku gospodarce opartej na wiedzy, w: Państwa battyckie..., s. 213-224.

${ }^{22} \mathrm{~W}$ roku 1997 z kolei zanotowano najwyższe wskaźniki dla pierwszych dziesięciu lat niepodległości, odpowiednio 10,6 dla Estonii, 8,6 dla Łotwy i 7,4 dla Litwy, Transition Report 1999. Ten years of transformation, EBRD, London 1999, s. 73-74.

${ }^{23}$ W 2002 roku kursy walut państw bałtyckich zostały powiązane z euro.

${ }^{24}$ W. Kosiedowski, Transformacja systemowa państw battyckich.., s. 32-33; E. Reichmann, Transformacja systemowa i stosunki zewnętrzne państwa nadbałtyckich: ocena porównawcza, Prace i Materiały Instytutu Gospodarki Światowej, nr 235, SGH, Warszawa 2002, s. 14. 


\begin{tabular}{|c|c|c|c|c|c|c|}
\hline Państwo & 1996 & 2000 & 2004 & $\begin{array}{c}\text { Zmiana w punktach } \\
\text { procentowych } \\
\text { w latach 1996-2004 }\end{array}$ & $\begin{array}{c}\text { Zmiana w punktach } \\
\text { procentowych } \\
\text { w latach 2000-2004 }\end{array}$ & $\begin{array}{c}\text { Zmiana w punktach } \\
\text { procentowych } \\
\text { w latach 1996-2004 }\end{array}$ \\
\hline Litwa & 36,8 & 39,3 & 50,5 & 2,5 & 11,2 & 13,7 \\
\hline Lotwa & 32,4 & 36,7 & 45,7 & 4,3 & 9,0 & 13,3 \\
\hline
\end{tabular}

Źródło: W. Kosiedowski, Transformacja systemowa państw baltyckich.., s. 38.

Tabele nr 2 i 3 wskazują zasadnicze punkty w procesie integracji gospodarczej ze strukturami Unii Europejskiej. Kolejne etapy były charakterystyczne dla wszystkich państw kandydujących. Tym niemniej widać jest podstawowe mechanizmy regulujące dynamikę akcesji.

Tabela 3. Podstawowe umowy ekonomiczne zawarte między EU a państwami bałtyckimi

\begin{tabular}{|c|c|c|c|}
\hline umowa & podpisana & Wejście w życie & Główne założenia \\
\hline $\begin{array}{c}\text { Umowa o handlu } \\
\text { i współpracy }\end{array}$ & 11.05 .92 & $\begin{array}{c}1.02 .1993 \mathrm{dla} \\
\text { Łotwy i Litwy, } \\
1.03 .93 \mathrm{dla} \\
\text { Estonii }\end{array}$ & $\begin{array}{c}\text { Wprowadzono status najwyższego } \\
\text { uprzywilejowania i niedyskryminacji we } \\
\text { współpracy na niektórych płaszczyznach }\end{array}$ \\
\hline $\begin{array}{c}\text { Agreements } \\
\text { on Trade and } \\
\begin{array}{c}\text { Trade-related } \\
\text { Matters(TRIMs) }\end{array}\end{array}$ & 18.07 .1994 & 1.01 .1995 & $\begin{array}{c}\text { Liberalizacja w oparciu o zasady GATT, } \\
\text { czteroletni okres przejściowy dla Łotwy } \\
\text { i sześcioletni dla Litwy dla handlu, } \\
\text { wspólne komisje do wdrażania umowy }\end{array}$ \\
\hline $\begin{array}{c}\text { Umowa } \\
\text { stowarzyszeniowa }\end{array}$ & 12.06 .95 & 1.02 .1998 & $\begin{array}{c}\text { Przygotowanie państw bałtyckich do } \\
\text { warunków członkowskich }\end{array}$ \\
\hline
\end{tabular}

Źródło: R. Vilpišauskas, G. Steponavičiene, The Balic States: The Economic Dimension, w: red. H. Tang, Winners and Losers of European Integration: Policy Issues for Central and Eastern..., s. 69.

Tabela 4. Instrumenty integracji państw bałtyckich z UE

\begin{tabular}{|c|c|}
\hline Instrument umowy & Główne założenia umowy \\
\hline Program PHARE & $\begin{array}{l}\text { Wsparcie techniczne i finansowe dla rozwoju państw } \\
\text { kandydujących }\end{array}$ \\
\hline $\begin{array}{c}\text { Biała Księga dotycząc } \\
\text { przygotowania państw ES-W do } \\
\text { integracji ze wspólnym rynkiem }\end{array}$ & Przejrzenie obszarów w których należy wprowadzić acquis \\
\hline Umowy stowarzyszeniowe & $\begin{array}{l}\text { Zdefiniowanie obszarów związanych ze spełnianiem } \\
\text { kryteriów kopenhaskich }\end{array}$ \\
\hline $\begin{array}{c}\text { Narodowe programy włączenia } \\
\text { acquis }\end{array}$ & $\begin{array}{l}\text { W oparciu o opinie i raporty proces wdrażania dorobku } \\
\text { wspólnotowego }\end{array}$ \\
\hline screening & $\begin{array}{c}\text { Przegląd zgodności prawa wewnętrznego z prawem } \\
\text { wspólnotowym. }\end{array}$ \\
\hline twinning & $\begin{array}{l}\text { wsparcie procesów dostosowawczych prawa do unijnego, } \\
\text { a także przygotowanie do realizacji unijnych polityk. }\end{array}$ \\
\hline Negocjacje akcesyjne & Rozpoczęly się wiosną 2000 roku \\
\hline
\end{tabular}

Źródło: R. Vilpišauskas, G. Steponavičiene, The Balic States: The Economic Dimension, w: red. H. Tang, Winners and Losers of European Integration: Policy Issues for Central and Eastern..., s. 70 
Po bardzo korzystnym okresie tuż po akcesji do Unii państwa bałtyckie zostały dotknięte przez panujący w Europie kryzys. Gospodarki „bałtyckich tygrysów" różnie na niego zareagowały. W 2009 roku gospodarka Łotwy skurczyła się o 18 proc., Litwy - o 14,7 proc., Estonii - o 13,9 proc $^{25}$. Wąskie specjalizacje i uzależnienie od obcego kapitału spowodowało krach na Łotwie i Litwie. Łotwa zdecydowała się skorzystać z pomocy MFW, na Litwie która tego nie zrobiła, rozpoczęto proces cięć budżetowych. Najmniej odczuła kryzys Estonia której rząd wykorzystując wcześniejsze nadwyżki w budżecie postanowił wprowadzając euro dokonać koniecznych cięć. W drugiej połowie 2010 roku wszystkie trzy państwa bałtyckie wyszły z recesji, ale gospodarka Litwy urosła tylko 0,5 proc., podczas gdy PKB Łotwy wzrosło o 2,7 , a Estonii $7 \%{ }^{26}$ - o 4,7 proc. We wszystkich trzech państwach bezrobocie utrzymywało się w tym czasie w okolicach $15 \mathrm{proc}^{27}$, w roku 2016 bezrobocie kształtowało się już na poziomie 6,8\% w Estonii, 7,9 na Litwie i 9,6\% na Łotwie. Obecnie(2020 rok) odpowiednio na Łotwie i Litwie $8 \%$, w Estonii $7 \%{ }^{28}$.

Wszystkie trzy państwa bałtyckie wprowadziły też już walutę euro - Estonia w 2011 roku, Łotwa w 2014 roku, a Litwa w 2015 roku. Bardzo różnie wprowadzenie euro przyjęli obywatele państw bałtyckich. Najbardziej docenili przyjęcie euro Estończycy(45\%). Na Lotwie i Litwie społeczeństwa dzielą się na trzy grupy o podobnej wielkości, tych którzy widzą korzyści z przyjęcia euro, tych którzy uważają, ze przyjęcie euro jest niekorzystne oraz ci którzy uważają, że bilans zysków i strat równoważy się. Zarówno na Łotwie jak i w Estonii mniejszość rosyjska raczej opowiada się po stronie strat(odpowiednio - 35\% i 45\%) niż korzyści $(25 \%$ i 22\%) niż pozostałe osoby ( $21 \%$ badanych narodowości łotewskiej i $16 \%$ estońskiej $)^{29}$.

Warto również zwrócić uwagę na inne wskaźniki pokazujące jak na przestrzeni lat 2004-2021 zmieniała się pozycja państw bałtyckich w rankingach międzynarodowych i jak awansowały w tych rankingach te państwa.

${ }^{25}$ Więcej pod adresem http://www.polityka.pl/swiat/analizy/1512462,1,kraje-nadbaltyckie-ida-wlasna-droga.read\#ixzz282H8jxpW, 12.12.20, R. Vilpišauskas, G. Steponavičiene, The Balic States: The Economic Dimension, w: red. H. Tang, Winners and Losers of European Integration: Policy Issues for Central and Eastern..., s. 52-68.

${ }^{26}$ M. Gołębiowska, Gospodarki Europy Środkowej: różne oblicza pandemii COVID-19, https:// ies.lublin.pl/wp-content/uploads/2021/04/komentarze-ies-383-80-2021.pdf, data dostępu:13.12.21.

${ }^{27}$ R. Vilpišauskas, G. Steponavičiene, The Balic States..., s. 52-68.

${ }^{28} \mathrm{https} / / /$ ec.europa.eu/eurostat/web/main/search?p_p_id=estatsearchportlet_WAR_estatsearchportlet_INSTANCE_bHVzuvn $1 \mathrm{SZZJ} \& \mathrm{p} \_\mathrm{p} \_$lifecycle=1\&p_p_state=maximized\&p_p_mode $=$ view\&_estatsearchportlet_WAR_estatsearchportlet_INSTANCE_bHVzuvn1SZ8J_action=search\&_estatsearchportlet_WÄR_estatsearchportlet_INSTANCE_bHVzuvn1SZ8J_theme=PER GENSTA\&p_auth=n0SQN-̄6gx\&text=unemployment+2020, data dostępu: 17.12 .20

29 A. Fuksiewicz, A. Łada, (2015), Grupa Baltycka, Litwa, Łotwa i Estonia w poszukiwaniu wspólnych interesów, Warszawa 2015,Tamże, s. 40. 
Tabela nr 5. Wybrane wskaźniki rozwoju gospodarczego

\begin{tabular}{|c|c|c|c|}
\hline & Litwa & Łotwa & Estonia \\
\hline & 20042011 & 20042011 & 20042011 \\
\hline Wskaźnik Rozwoju & $39(2003$ na 177) 40 & 4848 & 3834 \\
Społecznego & $2017-34$ & $2017-37$ & $2017-29$ \\
\hline Wskaźnik Jakości Życia & $63($ na 111) 73(2010) & $6670(2010)$ & $6871(2010)$ \\
& $22(2020)$ & $31(2020)$ & $10(2020)$ \\
\hline Wskaźnik Wolności & $23(2005) 23(2012)$ & $28(2005) 56(2012)$ & $4(2005) 16(2012)$ \\
Gospodarczej & $15(2021)$ & $30(2021)$ & $8(2021)$ \\
\hline Wskaźnik & $38(2007-2008)$ & $45(2007-2008)$ & $27(2007-2008)$ \\
Konkurencyjności & $41(2017 / 18)$ & $54(2017 / 18)$ & $29(2017 / 18)$ \\
Gospodarki & & & \\
\hline Wskaźnik Percepcji & $44(146) 48(2012)$ & $57(146) 54(2012)$ & $31(146) 32(2012)$ \\
Korupcji & $35(2020)$ & $42(2020)$ & $17(2020)$ \\
\hline
\end{tabular}

Źródła: opracownianie własne na podstawie: Human Development Index, http://hdr.undp.org/en/media/ HDR05_HDI1.pdf, 2010- http://hdr.undp.org/en/media/HDR_2010_EN_Table1_reprint.pdf, http://hdr. undp.org/en/2020-report, http://hdr.undp.org/en/statistics/, http://www.heritage.org/index/ranking?src=home, https://www.heritage.org/index/ranking?src=home, http://www.transparency.org/cpi2012/results, http://www. economist.com/media/pdf/QUALITY_OF_LIFE.pdf, http://www1.internationalliving.com/qofl2010/, https:// www.numbeo.com/quality-of-life/rankings_by_country.jsp?title=2020, http://reports.weforum.org/globalcompetitiveness-index-2017-2018/competitiveness-rankings/.

\section{POPARCIE DLA UNII EUROPEJSKIEJ}

Państwa bałtyckie reprezentowały i reprezentują niewielki potencjał gospodarczy, zarówno pod względem ekonomicznym jaki i demograficznym, to zaledwie 0,78\% udziału wszystkich trzech państw w PKB Unii Europejskiej. Tym niemniej w okresie około akcesyjnym dynamika rozwoju ekonomicznego stanowiła przedmiot zazdrości ze strony innych państw kandydujących. Liberalny model gospodarki który został przyjęty w państwach bałtyckich obok wyraźnych korzyści i możliwości rozwojowych wpłynął jednocześnie na podatność gospodarek Estonii, Litwy i Łotwy na światowy kryzys. Związek ze strukturami europejskimi niewątpliwie przyczynił się do wzmocnienie ich pozycji w regionie. Zwłaszcza w kontekście ich sąsiedztwa z Rosją i wielu nierozstrzygniętych jeszcze problemów wsparcie ze strony Unii było traktowane jako istotne ${ }^{30}$. Wybór proeuropejskiej opcji okazał się słusznym i dynamiczny rozwój gospodarczy jak również trudna transformacja polityczna wprowadziła społeczeństwa państw bałtyckich na nowe tory.

Estończycy od początku w większości okazywali zadowolenie z przystąpienia do struktur europejskich. Według badań EMOR ((Estonian Market Opinion Research) poparcie dla integracji w maju $2004 \mathrm{r}$. wahało się od 60 do 61 proc. Zgodnie z wynikami Eurobarometru z tego okresu, 56\% mieszkańców uważało, iż kraj

${ }^{30}$ A. Borek, ,, Wymiar pótnocny” w polityce Unii Europejskiej, Dialogi polityczne, nr 2 luty 2004, I. Budzyńska „Pólnocny wymiar" w polityce Unii Europejskiej, Informacja nr 658, http:// biurose.sejm.gov.pl/teksty/i-658.htm, data dostępu: 17.12.20. 
skorzystał na członkostwie w UE. Trzy lata później odsetek ten wzrósł do 72\%, zaś w maju 2007 roku według EMORu - osiągnął rekordowe 85\%. Pod koniec 2008 roku Estończycy obok Irlandczyków byli najbardziej zadowoloną z integracji nacją w Unii Europejskiej ${ }^{31}$. Z kolei Piotr Cichocki i Piotr Jakubowski przeanalizowali na podstawie badań Eurobarometru poparcie dla Unii Europejskiej w latach 20032007. Na pytanie związane z poczuciem związku z Unią Europejską(,_Ludzie mogą w różnym stopniu czuć się związani ze swoimi miastami lub wsiami, ze swoim regionem, ze swoim krajem lub z Europą. Proszę powiedzieć na ile czuje się Pan(i) związany(a): 1.z własnym krajem, 2. z Unią Europejską) odsetek osób wskazujących Wspólnotę jako źródło odniesienia zmniejszył się w stosunku do danych przedstawianych przez EMOR. We wszystkich państwach zaobserwowano wzrost ilości odpowiedzi wskazujących na identyfikację z państwem wśród osób starszych, inne zmienne(płeć, wykształcenie, zamożność, miejsce zamieszkania) nie były brane pod uwagę. Jedynie w Estonii uwzględniono dwa kryteria- płci- (tu większość mężczyzn wskazywała na przywiązanie do ojczyzny) i miejsca zamieszkania(przedstawiciele prowincji również wskazywali większe przywiązanie do państwa). Badania te pokazują pewną rozbieżność w stosunku do poparcia jakie dla integracji ze strukturami Unii Europejskiej zostało wyrażone w referendach akcesyjnych. Wskazywałoby to być może, że wybór na rzecz Unii podyktowany był pragmatyzmem. Z kolei badanie opinii publicznej z maja 2012 roku na pytanie dotyczące wskazania wpływu na poziom życia na poziomie unii, państwa i samorządu terytorialnego pokazało, że zarówno Litwini jak i Łotysze w 8\% wskazują UE(Estończycy 6\%). Na poziom państwowy wskazało $62 \%$ Litwinów, $57 \%$ Łotyszy i 44\% Estończyków, na poziom lokalny 26\% Litwinów, 32\% Łotyszów i najwięcej 46\% Estończyków ${ }^{32}$. W badaniu tym jednocześnie wskazano, że poczucie obywatelstwa wspólnotowego wskazuje 60\% Litwinów, 54\% Łotyszy i 67\% Estończyków. Badania przeprowadzone przez Eurobarometer w 2019 roku wskazało również, że obywatele państw bałtyckich na pytanie dotyczące pierwszego skojarzenia/uczucia w związku z UE wskazują zaufanie- Litwa 44\%, Estonia 33\% i wątpliwości Łotwa 30\%33, zaledwie 4\% Estończyków, 3\%Litwinów i 2\% Łotyszy wyraża obawy związane z Unią Europejskąa

${ }^{31}$ P. Słoń, Estonia - Zraniony tygrys nadbaltycki, http://www.psz.pl/tekst-19742/Estonia-5-lat-w -UE, data dostępu: 30.12.20.; P. Cichocki, P. Jakubowski, Poczucie zwiazku z Unia Europejska w nowych krajach członkowskich Europy Środkowo-Wschodniej, Przegląd Zachodni 2009, nr 3, s. 191-212, por. A. Albi, Referenda w sprawie czlonkostwa w UE w krajach Europy Środkowej i Wschodniej: konsekwencje dla unijnej procedury zmian traktatowych, Centrum Europejskie Natolin, Warszawa 2004, https://www. natolin.edu.pl/pdf/zeszyty/NatolinZeszyt10_AnelliAlbi.pdf, data dostępu: 23.11.20.

${ }^{32}$ Komisja Europejska, Standard Eurobarometr 77, European Citizenship-spring 2012, S.14, http://ec.europa.eu/public_opinion/archives/eb/eb77/eb77_citizen_en.pdf, data dostępu: 23.11.20; por. również K. Korzeniowska-Wołek, Opinia publiczna na Litwie wobec integracji europejskiej, Biuletyn PISM, nr 50, 2002, s. 495-498.

${ }^{33}$ Emotions and Political Engagement Towards the EU, (2019), https://www.europarl.europa eu/at-your-service/files/be-heard/eurobarometer/2019/emotions-and-political-engagement-towards-the-eu/report/en-flash-2019.pdf, s. 6, data dostępu: 23.11.20.

34 Tamże, s. 9. 


\title{
ZAKOŃCZENIE
}

Integracja państw bałtyckich ze strukturami Unii Europejskiej przyniosła tym państwom wiele korzyści i są to fakty zauważalne i docenianie w społeczeństwach tych państw. Wzrost gospodarczy, który zanotowały państwa bałtyckie zaraz po rozszerzeniu UE 2006 roku osiągnął w Estonii wartość 9,9\%, na Litwie 8\%, zaś na Łotwie 12,2\%). W latach 2004- 2015 fundusze UE (m.in. fundusze strukturalne, polityka spójności, PHARE) stanowiły 1,5-2,9\% PKB Łotwy, dzięki czemu w 2010 r. PKB na mieszkańca został podniesiony do poziomu $56 \%$ średniej UE ${ }^{35}$. Jeszcze lepsze wyniki zanotowały Litwa 61\% i Estonia 67\% ${ }^{36}$. W 2018 roku Unia Europejska przekazała Litwie 2.071 miliardów (co stanowiło $4.80 \%$ gospodarki Litwy), Estonii 0.759 miliarda euro(co stanowiło $3.03 \%$ gospodarki Estonii) i 1.212 miliarda euro Łotwie(co stanowiło $4.14 \%$ gospodarki Łotwy) $)^{37}$. Pomimo różnic w rozwoju gospodarczym i odmiennym problemom jakim państwa te stawiały czoła wyraźnie zakres oddziaływania Unii Europejskiej sprzyjał ich rozwojowi. I nawet w obliczu pandemii Covod-19 badanie opinii publicznej wskazało, że wskazało, 81\% Litwinów, 79\% Estończyków i 76\% Łotyszy czuje się obywatelami Unii Europejskiej ${ }^{38}$.

Title: 15 years of the Baltic states in the European Union as in view of the public opinion - initial assessment.

\begin{abstract}
Abstrakt: In the Baltic states, both at the accession stage and now, high support for the European Union can be seen. The aim of the article is to analyze the process of joining the European Union by the three Baltic states and to analyze the fifteen years in this organization. The subject of research will also be the social perception of European integration in these countries.
\end{abstract}

Keywords: Baltic States, European Union, public opinion

\section{BIBLIOGRAFIA}

1. 15 lat państwa Europy Środkowo- Wschodniej w Unii Europejskiej. Raport, (2019), red. Surmacz B., Stępniewski T., Prace IEŚ Zeszyt 5.

2. 2007 Memorandum of CoE Commissioner for Human Rights, https://wcd.coe.int/ViewDoc. jsp?id=1134279\&BackColorInternet=FEC65B\&BackColorIntranet=FEC65B\&BackColorLogged=FFC679\#P425_70374.

${ }^{35}$ A. Kuczyńska- Zonik, Łotwa, Prace IŚE, nr 5/2019, s. 102

${ }^{36}$ https://ec.europa.eu/eurostat/web/products-statistical-books/-/ch_01_2010_xls, data dostępu: 12.12.20.

37 https://european-union.europa.eu/principles-countries-history/country-profiles_pl, data dostępu: 17.09.20.

${ }^{38}$ https://europa.eu/eurobarometer/surveys/detail/2230, data dostępu: 12.12.20. 
3. Albi A., (2004), Referenda w sprawie członkostwa w UE w krajach Europy Środkowej i Wschodniej: konsekwencje dla unijnej procedury zmian traktatowych, Centrum Europejskie Natolin, Warszawa.

4. Borek A., (2004), ,, Wymiar pótnocny” w polityce Unii Europejskiej, Dialogi polityczne, nr 2 luty.

5. Budzyńska I., (2000), „Pólnocny wymiar” w polityce Unii Europejskiej, Informacja nr 658, http://biurose.sejm.gov.pl/teksty/i-658.htm.

6. CEPA Resolution No. 1527 (2006).

7. Cichocki P., Jakubowski P., (2009), Poczucie zwiazku z Unia Europejska w nowych krajach członkowskich Europy Środkowo-Wschodniej, „Przegląd Zachodni”, nr 3.

8. Dziuba J., (2008), Gra mniejszościa rosyjska, http://www.psz.pl/tekst-10773/Joanna-DziubaGra-mniejszoscia-rosyjska.

9. Enlargement of the European Union, (2009)red Alan F. Tatham, Kluwer Law International.

10. Fuksiewicz A., Łada A., (2015), Grupa Bałtycka, Litwa, Łotwa i Estonia w poszukiwaniu wspólnych interesów, Warszawa.

11. Góralski W. M., (2007), Unia Europejska. Tom II. Gospodarka - Polityka - Wspótpraca. Wolters Kluwer Polska Sp. z o.o., 2007.

12. http://eur-lex.europa.eu/pl.

13. http://hdr.undp.org/en.

14. http://www.cie.gov.pl.

15. http://www.cilevics.eu.

16. http://www.csb.gov.lv/en.

17. http://www.economist.com.

18. https://european-union.europa.eu.

19. http://www.heritage.org.

20. http://www.letton.ch.

21. http://www.lietuva.pl.

22. http://www.transparency.org.

23. http://www.xxiamzius.lt.

24. http://www1.internationalliving.com.

25. Janusz G., (2011), Ochrona praw mniejszości narodowych w Europie, Lublin.

26. Kaiser U., (2005), The Balic States As Members of the European Union- an Analysis of the public opinion to EU membership in the Baltic Region, GRIN Verlag 2005.

27. Korzeniowska-Wołek K., (2002)Opinia publiczna na Litwie wobec integracji europejskiej, Biuletyn PISM, nr 50, 2002.

28. Latvijas psr Augstākās Padomes lēmums par Latviešu valodas statusu(łot.), (2012) http://www. vvk.lv/index.php?sadala=135\&id=167, 12.12.21.

29. Miniotaitė G., Jakniūnaitė D., (2001), Lietuvos saugumo politika ir identitetas šiuolaikiniu saugumo studiju kontekste, Politologia 3.

30. Obawy i nadzieje społeczeństwa Estonii zwiazane z integracja z strukturami Unii Europejskiej w kontekście referendum akcesyjnego, (2007), „Annales Academiae Paedagogicae Cracoviensis. Studia Politologica III", Wydawnictwo Naukowe Akademii Pedagogicznej, Kraków.

31. Państwa bałtyckie w zintegrowanej Europie, (2011), red. J.W. Gołębiowski, Warszawa. 
32. Raś K., (2017), Elektroenergetyka - kolejny cel państw battyckich w uniezależnianiu się od Rosji, Biuletyn PISM, Nr 56 (1498).

33. Reichmann E., (2002), Transformacja systemowa i stosunki zewnętrzne państwa nadbaltyckich: ocena porównawcza, Prace i Materiały Instytutu Gospodarki Światowej, nr 235, SGH, Warszawa.

34. Rossa- Kilian D., (2008), Struktura etniczno- kulturowa regionu Morza Battyckiego, Zeszyty Naukowe Akademii Marynarki Wojennej, rok XLIX nr 1(172).

35. Słoń P., Estonia - Zraniony tygrys nadbattycki, http://www.psz.pl/tekst-19742/Estonia-5-lat-w -UE.

36. Sytuacja polityczna, rzady prawa i przestrzeganie praw czlowieka w krajach transformacji w latach 2003-2006, red. A. Rzepiński, M. Kmak, K. Oponowicz, http://www.forum-ekonomiczne.pl/public/upload/ibrowser/raporty/NE2004/Raport2004_pol_II.pdf.

37. The Balic States, (2005), Amsterdam, New York.

38. Transition Report 1999. Ten years of transformation, (1999), EBRD, London.

39. Trocikowski T., Stopień poparcia społeczeństwa Estonii dla integracji z Unia Europejska http:// www.exporter.pl/forum/rynki_wschodnie/Estonia_unia.html.

40. UN Special Rapporteur on contemporary forms of racism, racial discrimination, xenophobia and related intolerance - Paragraf 89

41. Van Elsuwege P., (2008), From Soviet Republics to EU Member States: A Legal and Political Assessment., Koninklijke Brill NV. 